Revision Article \title{
Colostomy irrigation: review of a number of technical
aspects*
}

\author{
Irrigação da colostomia: revisão acerca de alguns aspectos técnicos
}

Irrigación de la colostomía: revisión sobre algunos aspectos técnicos

\section{Isabel Umbelina Ribeiro Cesaretti ${ }^{1}$, Vera Lúcia Conceição de Gouveia Santos ${ }^{2}$, Sandra Soares Schiftan ${ }^{3}$, Lucila Amaral Carneiro Vianna ${ }^{4}$}

\begin{abstract}
Objective: Performing a literature review about four technical aspects related to the colostomy irrigation: volume of water to be infused, postoperative moment to start the method's training sessions, maintenance of a 24-hour interval between the colostomy irrigations, and time spent for the execution of the procedure, aiming to contribute for the most adequate systematization of the method. Methods: After searching in the designated sources, sixty-three articles were identified. Results: It was observed that there is no consensus among the several authors: the volume of infused water varied from $500 \mathrm{ml}$ to $1500 \mathrm{ml}$, although, in the clinical practice, the average infused volume is $1000 \mathrm{ml}$; the postoperative moment to start the training sessions varied from five days to six months; the maintenance time of a 24-hour interval between the colostomy irrigations varied from two weeks to six months; time spent in the execution of the procedure varied from 20 to 90min. Conclusion: The knowledge of these results may be an encouragement to the nurses, especially stomatherapists, to reevaluate their practice, in order to standardize the technical aspects related to the procedure, having as basis the specialized assistance.
\end{abstract}

Keywords: Colostomy/irrigation; Nursing care

\section{RESUMO}

Objetivo: Realizar uma revisão bibliográfica sobre quatro aspectos técnicos relacionados à irrigação da colostomia: volume de água a ser infundido, momento do pós-operatório em que se deve iniciar o treinamento para uso do método, tempo de manutenção de 24 horas como intervalo entre as irrigações e tempo gasto na realização do procedimento, visando contribuir para a sistematização mais adequada do método. Métodos: Feitas as buscas nas fontes planejadas, foram identificados 63 artigos. Resultados: Observou-se a inexistência de um consenso entre os diversos autores consultados: o volume de água infundido variou de $500 \mathrm{ml}$ a $1500 \mathrm{ml}$, embora, na prática, o volume médio infundido seja de $1000 \mathrm{ml}$; o momento do pós-operatório para início do treinamento variou de cinco dias a seis meses; o tempo de manutenção do intervalo de 24 horas entre as irrigações variou de duas semanas a seis meses; o tempo dispendido na realização do procedimento variou de 20 a 90 minutos. Conclusão: $O$ conhecimento desses resultados pode servir de estimulo aos enfermeiros, preferencialmente estomaterapeutas, para reavaliar a sua prática, a fim de padronizar os aspectos técnicos a esta relacionados, tendo como pano de fundo a assistência especializada.

Descritores: Colostomia/irrigação; Cuidados de enfermagem

\section{RESUMEN}

Objetivo: Realizar una revisión bibliográfica sobre cuatro aspectos técnicos relacionados a la irrigación de la colostomía: volumen de agua a ser infundido, momento del post-operatorio en que se debe iniciar el entrenamiento para el uso del método, tiempo de manutención de 24 horas como intervalo entre las irrigaciones y tiempo gastado en la realización del procedimiento, visando contribuir en la sistematización más adecuada del método. Métodos: Una vez realizadas las búsquedas en las fuentes planificadas, fueron identificados 63 artículos. Resultados: Se observó la inexistencia de un consenso entre los diversos autores consultados: el volumen de agua infundido varió de $500 \mathrm{ml} \mathrm{a} 1500 \mathrm{ml}$, aunque, en la práctica, el volumen promedio infundido sea de $1000 \mathrm{ml}$; el momento del post-operatorio para el inicio del entrenamiento varió de cinco días a seis meses; el tiempo de manutención del intervalo de 24 horas entre las irrigaciones varió de dos semanas a seis meses; el tiempo utilizado en la realización del procedimiento varió de 20 a 90 minutos. Conclusión: El conocimiento de esos resultados puede servir de estímulo a los enfermeros, preferentemente estomaterapeutas, para reevaluar su práctica, a fin de patronizar los aspectos técnicos relacionados con ella, teniendo como cortina de fondo la asistencia especializada.

Descriptores: Colostomía/irrigación; Cuidados de enfermería

\footnotetext{
* The study was accomplished at Escola Paulista de Enfermagem the Universidade Federal de São Paulo - UNIFESP - São Paulo (SP), Brazil, in a Graduate Program.

${ }^{1}$ Graduate student at the Nursing Department at the Universidade Federal de São Paulo - UNIFESP - São Paulo (SP), Brazill.

${ }^{2}$ Associate Professor at the Medical-Surgery Nursing Department of the Escola de Enfermagem at USP São Paulo (SP), Brazil.

${ }^{3}$ Stomatherapist Nurse, responsible for Stoma Sector at the Specialty Outpatient Clinic at the Heliópolis Hospital Complex - São Paulo (SP), Brazil.

${ }^{4}$ PbD, Full Professor at the Nursing Department of the Universidade Federal de São Paulo - UNIFESP - São Paulo (SP), Braz̧il.
} 


\section{INTRODUCTION}

Colostomy irrigation is a method for the regulation of the intestinal activity of colostomized patients, followed by intestinal washing (enema), done in the stoma, in which a specified volume of liquid is used, usually water at body temperature to clean the large intestines and that allows the control the elimination of feces by colostomy for a regular period of time ${ }^{(1-6)}$.

Physiologically, the introduction of a volume of water in the colon causes a structural dilation, which stimulates contraction (mass peristalsis), thus promoting the emptying of the fecal content. Besides, it reduces the formation of gas since, by removing the residues, the bacterial microbiota is reduced quantitatively, and consequently the production of gases is also reduced ${ }^{(1,7-9)}$. The basic purpose of this procedure is to train the intestine to evacuate fecal contents once a day or every two days at a planned time, giving the colostomized person a period exempt of worries about the collecting device ${ }^{(7)}$ and improving their quality of life.

The indication of this method is medical, and the training is responsibility of a nurse, preferentiallya stomatherapist. To start it, the colostomized person must meet some criteria: having terminal colostomy in the descending or sigmoid colons; having dexterity, physical and mental ability to perform it; absence of complications in the stoma (serious prolapse of the ileal seromuscular tube, stenosis, retraction or large parastomy hernia); not having irritable colon syndrome ${ }^{(9-13)}$, and having good sanitation in their homes ${ }^{(6,8,14)}$.

According to O'Bichere et $\mathrm{al}^{(15)}$, the first colostomy irrigation was introduced by Duret over two hundred years ago to clean the colon of a child who underwent intestinal obstruction surgery. On the other hand, other authors reported the suggestion by Pillore \& Fine, in the middle of the XVIII century, as a method of controlling the elimination of feces from the stoma. Therefore, the procedure was only presented after the publications of Lockhart-Mummery (England), in 1927, which he enthusiastically defended ${ }^{(16-20)}$. Years later, the presentation of studies announcing the occurrence of intestinal perforations and informing that only one-third of the studied persons who used it regularly, kept using it, disturbed its usage. Such facts influenced it negatively and contributed for its abandonment in England and other European countries ${ }^{(16-18,20-22)}$. Finally, from 1950 onwards, with the technological advances reached in the specific equipment, building a malleable cone-shaped extremity, the method became widely used, especially in the United States. Later, the presentation of this knowledge, added to the better sanitary conditions of the population, improved the credibility of the method, which also started being used in European countries ${ }^{(8,16,20,22-24)}$. Hotteinstein ${ }^{(25)}$ reports that stomatherapist nurses were responsible for several positive changes for the activities developed on colostomized persons and in collaboration with industries that manufacture the specific equipment.

There are few studies presented about colostomy irrigation nowadays, although there are still doubts about the necessary standardization, such as: the volume of water to be infused, when to start the method, how long the 24-hour frequency must be kept between an irrigation and another and the time spent on the procedure. These aspects were determined more because of tradition than evidence. In this regard, when Turnbull ${ }^{(26)}$ came to know that the procedure was performed by non-stomatherapist nurses in people who lived in nursing homes or even in their own houses in the United States, noted the importance of some criteria for the care: recycling and training, systematization of the equipment and specific protocols for data registration, in order to have a panoramic view for the healthcare of this clientele.

It is necessary to have all the equipment to perform the procedure: a transparent irrigation container, with a measurement scale, temperature indicator of water and capacity of $2000 \mathrm{ml}$; malleable plastic cone; transparent tube or plastic extension to connect the irrigator to the cone, which contains a clamp to control the water flow; a transparent draining bag, open in both extremities, with an adhesive or support for an elastic belt around the wider end; loop for closing the draining bag, an elastic belt (Table 1) and other accessories that may be necessary: a crane where water recipient can be hung, procedure gloves; water at body temperature; a jar of warm water; lubricant; usual hygiene material ${ }^{(2,6,9,12,27)}$ and collecting equipment or occluding system $^{(27)}$, to be used after the procedure is performed.

Having in mind the contribution for a more adequate systematization of colostomy irrigation, this study was a literature review about the following technical aspects: volume of water to be infused, the postoperative moment to start the method's training sessions, maintenance of a 24-hour interval with breaks and time spent for the execution of the procedure.

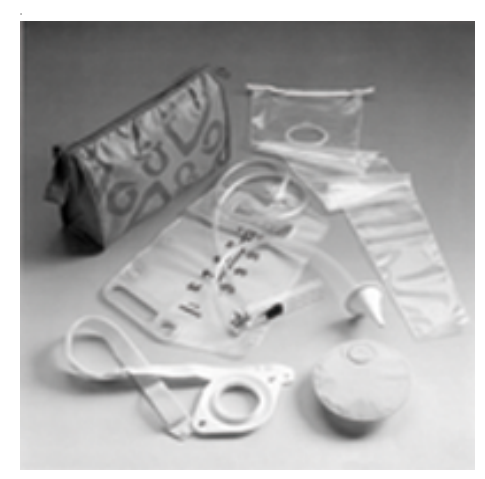

Figure 1 - Colostomy Irrigation Kit. 


\section{METHODS}

This study is a literature review, a method concerning research on literature that has already been published in books, magazines, separate publications and written media about the topic, aiming to support the investigation related to the study proposed ${ }^{(28-29)}$.

The material was composed by: articles published in national and international journals about colostomy irrigation and presented in the following databases: PUBMED, LILACS and GOOGLE, from 1970 to 2006; articles in the magazine published by the manufacturing company of the specific devices for colostomy irrigation and in the annals of the World Council of Enterostomal Therapists from a private collection; and also book chapters. For the search, the following descriptors were used: colostomy irrigation, irrigación de la colostomia, irrigation des colostomies, irrigazione della colostomia e irrigação da colostomia.

The adopted criteria for choosing articles was: being about the topic; being indexed in the referred database; being integrally available and in the descriptor languages used for data collection. Once identified, the articles were analyzed and the data were recorded in a form, containing: title, author(s), periodic and technical aspects to be researched, according to the objective proposed. After a preliminary analysis of the chosen articles, the data were organized in tables.

\section{RESULTS}

Sixty-two studies were identified. three articles published before 1970 were included due to the importance of the content. Of these, 48 mentioned at least one of the four aspects studied, according to Charts 1-4.

Chart 1 - Authors and respective results or recommendation concerning the infused water volume in colostomy irrigation

\begin{tabular}{|c|c|}
\hline Author & Water Volume \\
\hline Kretschmer ${ }^{(7)}$ & $\begin{array}{l}500 \mathrm{ml} \text { in the first irrigation and } \\
1000 \mathrm{ml} \text { maintenance }\end{array}$ \\
\hline Ventafridda and Zanolla ${ }^{(30)} ;$ Garcia, Carmona and Melero ${ }^{(2)} ; \operatorname{Helios}^{(14)}$ & 500 to $1500 \mathrm{ml}$ \\
\hline Erwin-Toth and Doughty ${ }^{(9)}$ & 600 to $1000 \mathrm{ml}$ \\
\hline Montandon $^{(31)}$ & 700 to $1000 \mathrm{ml}$ \\
\hline $\begin{array}{l}\text { McConnell( }{ }^{(32)} \text { Christensen et al(33); Pullen }{ }^{(34)} \text {; Santos et al }{ }^{(35)} \text {; Galliani et al }{ }^{(30)} \text {; } \\
\text { Santos, Cesaretti and Ribeiro }{ }^{(12)}\end{array}$ & 750 to $1500 \mathrm{ml}$ \\
\hline Terranova et al ${ }^{(37)}$ & 800 to $1000 \mathrm{ml}$ \\
\hline Casas, Cabrejas and Domenec ${ }^{(5)}$ & 800 to $1200 \mathrm{ml}$ \\
\hline Baumel et al ${ }^{(38)}$; Jao et al ${ }^{(18)}$; Ortiz, Martí Rague and Foulkes ${ }^{(39)}$ & $1000 \mathrm{ml}$ \\
\hline $\begin{array}{l}\text { Tejido Valenti and Vargas Laguna }{ }^{(1,51)} \text {; Stockley( }{ }^{(8)} \text {; Blackley(}{ }^{(6)} \text {; Valenti, Salabert } \\
\text { and Borsot( }{ }^{(40)}\end{array}$ & 1000 to $1500 \mathrm{ml}$ \\
\hline Gattuso et al $\mathrm{l}^{(41)}$ & $1500 \mathrm{ml}$ \\
\hline
\end{tabular}

Chart 2 - Authors and respective result or recommendation as a postoperation moment in which the colostomy irrigation training must start.

\begin{tabular}{|c|c|}
\hline Author & Time to start \\
\hline Kretschmer $^{(7)}$ & Fifth to eighth day post-operation (PO) \\
\hline Mazier et al ${ }^{(20)}$ & sixth day PO \\
\hline Laucks et al(19); Viso, Beatobe and Galofré(42) & nineth day $\mathrm{PO}$ \\
\hline Montandon ${ }^{(31)}$ & tenth day PO \\
\hline Blackley$^{(())}$ & tenth day PO to six weeks \\
\hline Perboni et al ${ }^{(43)}$ & $\begin{array}{l}\text { Early postoperatory, without stipulating a } \\
\text { specific day. }\end{array}$ \\
\hline Sadahiro et al(44) & Fourteenth to thirtieth day $\mathrm{PO}$ \\
\hline Terranova et al ${ }^{(37)}$; Suwanna et al ${ }^{(4)}$ & Two weeks \\
\hline Gabrielli et al ${ }^{(16)}$ & two to three weeks \\
\hline Santos, Cesaretti and Ribeiro ${ }^{(12)}$ & minimum of four weeks \\
\hline Ortiz, Martí Rague and Foulkes ${ }^{(39)}$ & six weeks \\
\hline Christensen et al ${ }^{(33)}$ & second or third month \\
\hline Rogenski, Baptista and Rogenski ${ }^{(45)}$ & Between the second and sixth month \\
\hline Stockley $^{(8)}$; Woodhouse ${ }^{(13)}$; Williams and Johnston ${ }^{(22)}$; Plum ${ }^{(46)}$ & three months \\
\hline Shaz's ostomy page $e^{(47)}$ & four months \\
\hline Venturini et al(48) & about five months \\
\hline
\end{tabular}


Chart 3 - Authors and respective result or recommendation as for maintenance time of the 24 hours break between irrigations

\begin{tabular}{|l|c|}
\hline Author & Time of maintenance of a 24-hour frequency \\
\hline Stockley ${ }^{(8)} ;$ Garcia, Carmona and Melero $^{(2)}$ & Two weeks \\
\hline Erwin-Toth and Doughty ${ }^{(9)}$ & three to six weeks \\
\hline Kretschmer $^{(7)}$ & Six to eight weeks \\
\hline Viso, Beatobe and Galofré & Two weeks to two months \\
\hline Santos et al ${ }^{(35)}$; Santos, Cesaretti and Ribeiro(12) & six months \\
\hline
\end{tabular}

Chart 4 - Authors and respective results or recommendation concerning the time spent in the procedure.

\begin{tabular}{|c|c|}
\hline Author & Time spent \\
\hline Terranova et al ${ }^{(37)}$ & 20 to $60 \mathrm{~min}$ \\
\hline Pietri, Domeniconi and Gabrielli(49); Valenti, Salabert and Borsot ${ }^{(40)}$ & about 30min \\
\hline Suwanna et al ${ }^{(4)}$ & $33 \mathrm{~min}$ \\
\hline Bail et al(50) & About 35min \\
\hline $\begin{array}{l}\text { Tejido Valenti and Vargas Laguna }{ }^{(51)} \text {; Garcia, Carmona and Melero }{ }^{(2)} \text {; Casas, } \\
\text { Cabrejas and Domenec( }{ }^{(5)} \text {; Erwin-Toth and Doughty(9); Santos, Cesaretti and } \\
\text { Ribeiro }^{(12)} \text {; Santos et al }{ }^{(35)} \text {; Shaz's ostomy page } \mathrm{e}^{(47)}\end{array}$ & 30 to $45 \mathrm{~min}$ ( $38 \mathrm{~min}$ in average) \\
\hline Castillo et al ${ }^{(3)}$; Berger ${ }^{(11)}$; Venturini et al ${ }^{(48)}$ & 30 to $60 \mathrm{~min}$ ( $45 \mathrm{~min}$ in average) \\
\hline Mazier et al ${ }^{(20)}$; Seargeant ${ }^{(52)}$ & 30 to $90 \mathrm{~min}$ (60min in average) \\
\hline Plum$^{(46)} ;$ Viso, Beatobe and Galofré( ${ }^{(42)}$ & 35 to $45 \mathrm{~min}$ (40min in average) \\
\hline Santos and Koizumi ${ }^{(24)}$; Santos et al ${ }^{(53)}$; Kostov et al ${ }^{(54)}$ & 40 to $60 \mathrm{~min}$ (50min in average) \\
\hline Jao et $\mathrm{al}^{(18)}$ & $45 \mathrm{~min}$ \\
\hline Kretschmer $^{(7)}$; Blackley ${ }^{(6)} ;$ Helios $^{(14)}$; Baumel et al ${ }^{(38)}$; Goode ${ }^{(55)}$ & 45 to $60 \mathrm{~min}$ (52min in average) \\
\hline Stockley ${ }^{(8)}$ & 45 to $75 \mathrm{~min}$ (60min in average) \\
\hline Williams and Johnston ${ }^{(22)}$ & $53 \mathrm{~min}$ \\
\hline Laucks et $\mathrm{AL}^{(19)}$ & $58 \mathrm{~min}$ \\
\hline $\begin{array}{l}\text { Erwin-Toth and Doughty }{ }^{(9)} \text {; Gabrielli et al } \mathrm{l}^{(16)} \text {; Doran and Hardcastle } \mathrm{e}^{(21)} \text {; } \\
\text { Terranova }{ }^{(23)} \text {; Ventafridda }{ }^{(30) ;} \text { Perboni et al } l^{(43)} \text {; Rogenski, Baptista and Rogenski }{ }^{(45)} \text {; } \\
\text { O'Bichere }^{(56)} \text {; Sanada }{ }^{(57)} \text {; Amdrup \& Christensen }{ }^{(58)}\end{array}$ & $60 \mathrm{~min}$ \\
\hline
\end{tabular}

\section{DISCUSSION}

Colostomy irrigation is an important method of intestinal control, because it regulates the elimination of feces through the stoma. However, more studies about the topic are necessary, not only for the presentation and introduction of this method in several services but also for the standardization of some practices not explored here.

Not long ago, in Brazil, several factors occurred, resulting in low usage and search for colostomy irrigation: lack of direction from the doctor in charge, by carelessness or lack of knowledge; insufficient number of stomaterapist nurses, related to the territorial extension; the motivation of the colostomized persons, when they were in later postoperation period; inadequate conditions of home sanitation and the difficulty in having access to specific equipment ${ }^{(12,45)}$. Nowadays, the method has become more widely-known, in response to the quantitative and qualitative education of specialist nurses and to the recent approval of the National Policy of Attention to People with Stomas*, which includes, stimulates and favors a greater dissemination of this process. The goal of investigating some technical aspects related to this method constitutes another reflection to subsidize future theoretical and practical studies, as well as a more adequate systematization in our area.

Regarding the volume of liquid infused in colostomy irrigation (Chart 1), the inexistence of a consensus among several consulted authors was observed, because the volume mentioned vary from $500 \mathrm{ml}$ to $1500 \mathrm{ml}$. In the clinical practice, the use of an average volume of $1000 \mathrm{ml}$ is observed. From the scintigraphic study accomplished by Meyhoff et $\mathrm{al}^{(59)}$, and comparing the use of three different volumes, $1000 \mathrm{ml}$ of water does not seems to be ideal for all people. In the authors' opinion, the $500 \mathrm{ml}$ volume is more appropriate, because the time of infusion and the water retention are lower, and the more consistent feces in the colon are completely removed. Besides, it is favored by the users. Opposed to it, Gattuso et $\mathrm{al}^{(41)}$ defend that the irrigation with $1500 \mathrm{ml}$ of water can be subjectively more effective. For Berger ${ }^{(11)}$, the amount of water that can be ingested is probably the safest for the procedure. On the other hand,

$\overline{* \text { www.sobest.org.br }}$ 
Tejido Valenti and Vargas Laguna ${ }^{(1)}$ and Stockley ${ }^{(8)}$ report the importance of planning the volume of water based on the physical constitution of the person, but they do not propose any way of planning it.

Recently, O'Bichere et al $(56,60)$ developed two comparative studies using water with a glyceryl trinitrate solution and water with a polyethylene glycol electrolyte solution (PEG), respectively. As results, the side effects were the main disadvantages in the use of trinitrate. The PEG was significantly better in emptying the colons, being a future alternative in colostomy irrigation.

The time when the procedure is performed is also related to the volume of infused liquid. For some authors, the colostomized person must choose the time that adapts better to their lifestyle, with adherence to said time and to the method used being important ${ }^{(5,7,12)}$. Regardles of the colostomy irrigation frequency, people must be aware that these two topics are essential for the intestinal training program. in order to keep it clean through the stimulation that the irrigation provides.

As for the postoperation moment in which the colostomy irrigation training must be started, the data in Chart 2 show some divergence among the several authors, showing periods varying from five days to six months. For nearly half of the authors, this training can be started before a 30-day postoperation period. The disagreement on the one hand, lies on the possibility of pain or discomfort to the recently-operated person ${ }^{(20)}$, and, on the other hand, the factor that colostomy irrigation would avoid the use of a collecting equipment to alleviate the stigma and the alteration of the affected body image, which would still be recommend for the hospitalized person ${ }^{(19,42)}$. Considering a later postoperative moment, Rogenski, Baptista e Rogenski ${ }^{(45)}$ consider that this training must start after the second month after the surgery, justifying that the person needs time to recover physically and adapt to the new situation. Other authors $^{(8,13,22)}$ mentioned the period of three months after surgery. Of these, Stockley ${ }^{(8)}$ stated that this time is enough to evaluate the person's acceptance and the home conditions, while Woodhouse ${ }^{(13)}$ says that the person would already be physically recovered from the surgery and willing to start the training. For times over three months ${ }^{(47-48)}$, no justification was given.

For the other studied aspect, the 24-hour maintenance time between each irrigation (Chart 3) varied from two weeks to six months. The frequency of the procedure must keep a relation with the postoperation evolution of the colostomized person. According to the references consulted, when colostomy irrigation is started, it must be performed daily, repeating it every 24 hours for a pre-programmed period. The response of the large intestines must be taken into account the for this training, which will vary from person to person. Also, the acquisition of the skills by the colostomized person would contribute for the progressive increasing of the method's effectiveness. From this period on, the frequency of irrigation may be modified to every 48 hours or even 72 hours, according to the joint evaluation from the colostomized person and the nurse, preferably a stomatherapist ${ }^{(12,35)}$.

There were controversies in the authors' opinions concerning the time spent during colostomy irrigation, varying from 20 minutes to 90 minutes (Chart 4). It was observed that, from the 35 authors consulted, nine mentioned a period of 60 minutes, while seven mentioned 30 to 45 minutes. The authors' opinion is that this time is compensated by the comfort of the inexistence of colostomy exonerations. In practice, the time spent is 60 minutes. Also, the authors mentioned report unanimously that there is no need for the person to stay in the bathroom during the procedure, being the person able to spend time with several activities, according to their wishes. Regardless, since the time spent is pointed out as the main disadvantage of the procedure $^{(8,12,23,35,43,55-57,61)}$, the decision to start the training program must come from the colostomized person, and must be based on their motivation and interest, supported by the understanding that it is and alternative resource for their rehabilitation.

By analyzing the technical aspects related to colostomy irrigation, some studies about safety and effective which prove the method are worth of note. For Galliani et $\mathrm{al}^{(36)}$, the water used in the colostomy irrigation does not seem to affect the colon mucosa, although an increase of epithelium cells renewal was observed in some subjects of the study. On the other hand, Sisco et $\mathrm{al}^{(62)}$, when analyzing the irrigation impact on intestine microbiota, report that irrigation could have an effect similar to antibiotics. Christensen et al $^{(33)}$, in a scintigraphic study of colostomy irrigation performed to evaluate the water transportation in colons, observed that the transversal and descending colon were complete emptied, as well as and $35 \%$ of the ascendant colon and cecum. Kostov et al( ${ }^{(54)}$, using ultrasonograghy to evaluate the colon lumen after to the colostomy, observed no image change, either before or after the training for colostomy irrigation. In a way, the studies proved that colostomy irrigation is a safe and efficient method, as long as the technical procedures and the use of adequate material are respected.

In the past years, the results obtained with the colostomized people for the use of colostomy irrigation as an intestinal control method, are responsible for the popularization of its use, particularly for the positive impact on the quality of life of these persons ${ }^{(63)}$. Some comparative studies, especially regarding the natural method, highlight the advantages of the irrigation, given the control obtained by most people in the elimination of feces and gases from the stoma ${ }^{(21-23,57-58)}$. Other results 
summarize the advantages of its use, relating them to the continence of colostomy. Colostomized persons report satisfaction with the method, the resulting security and comfort which are essential to their social reintegration ${ }^{(3,12,16,19,24,45,48,64)}$. This offers a better way of living with stoma, translated as better quality of life.

Safety, results, advantages offered from the method, the maintenance of all components of the healthcare team must be part of a "package" - especially the nurse, preferentially a stomaterapist - in which a colostomized person finds the basic motivation not only to facilitate their own participation in the process of colostomy irrigation training, but also to feel progressive improvements in their lifestyle in their permanent stomized condition.

\section{CONCLUSIONS}

The objective proposed for the study was

\section{REFERENCES}

1. Tejido Valenti M, Vargas Laguna M. El rol de enfermería frente a pacientes ostomizados. 3a ed. Barcelona: Rol; 1988. p. 31-5.

2. Molina Garcia AM, Guisado Carmona I, Valenciano Melero A. Atención integral al paciente ostomizado. Madrid: Coloplast Productos Médicos SA; 1992.

3. Castillo P, Coto MV, Hernández I, López A, López E, Moya MA, et al. Irrigación de la colostomía. ROL de Enfermería. 2000; 146: 59-61.

4. Suwanna K, Pensri B, Chatchanat N. Colostomy irrigation Thai style. WCET J. 2001; 21(2): 28-30.

5. Casas GV, Cabrejas PL, Domenec GA. Guía del ostomizado digestivo: cuidados de enfermería en la atención primaria. Madrid: Coloplast Productos Médicos SA; 1990.

6. Blackley P. Practical stoma wound and continence management. Vermont: Research Publications Py; 1998. p. 165-9.

7. Kretschmer KP. Estomas intestinais: indicações, métodos operatórios, cuidados, reabilitação. Rio de Janeiro: Interamericana; 1980. p. 88-92.

8. Stockley A. Irrigación. In: Breckman B. Enfermería del estoma. Madrid: Interamericana-McGraw Hill; 1990. cap. 11.p. 149-59.

9. Erwin-Toth P, Doughty DB. Principles and procedures of stoma management. In: Hampton BG, Bryant RA; International Association for Enterostomal Therapy. Ostomies and continent diversions: nursing management. St Louis: Mosby-Year Book; c1992. p. 29-103.

10. Abella MDH. Aproximación a la ostomía. ROL de Enfermería. 1988; 118: 5-15.

11. Berger M. Irrigation: a select option for a select population. In: $10^{\text {th }}$ Biennial Congress of the WCET, Yokohama; 1994. Proceedings. Yokohama, Japão: WCET; 1994. p. 206-7.

12. Santos VLCG, Cesaretti IUR, Ribeiro AM. Métodos de "controle" intestinal em ostomizados: auto-irrigação e sistema oclusor. In: Santos VLCG, Cesaretti IUR. Assistência em estomaterapia: cuidando do ostomizado. São Paulo: Atheneu; 2000. cap. 13. p. 245-62.

13. Woodhouse F. Colostomy irrigation: are we offering it enough? Br J Nurs. 2005; 14(16): S14-5.

14. Helios. La irrigación. Helios - La Revista Coloplast. 1995; accomplished and it was observed that there is no consensus among the several authors consulted, concerning the technical aspects sought. The volume of liquid infused varied from $500 \mathrm{ml}$ to $1500 \mathrm{ml}$; therefore, in practice, the average volume is $1000 \mathrm{ml}$; the postoperation moment to start the training the use of the method varied from six days to six months; the maintenance of the 24-hour interval between each irrigation varied from two weeks to six months, and the time spent performing the procedure was from 33 minutes to 90 minutes.

It is hoped that the knowledge of these results will become a form of encouragement to nurses, especially stomatherapists, to produce other studies about the topic and reevaluate its practice for a standardization of the related technical aspects, not only those mentioned in this study, but also others not explored here, concerning specialized and systematized healthcare assistance.

3(3): $11-3$.

15. O’Bichere A, Sibbons P, Doré C, Green C, Phillips RK. Experimental study of faecal continence and colostomy irrigation. Br J Surg. 2000; 87(7): 902-8.

16. Gabrielli F, Domeniconi R, Fazio FM, Ambrosi V. Risultati dell'irrigazione periodica nella riabilitazione del colostomizzato. Minerva Chir. 1980; 35(21): 1647- 54.

17. Grier WRN, Grier WR, Postel AH, Syarse A, Localio SA. An evaluation of colonic stoma management without irrigations. Surg Gynecol Obstet. 1964; 118:1234-42.

18. Jao SW, Beart RW Jr, Wendorf LJ, Ilstrup DM. Irrigation management of sigmoid colostomy. Arch Surg. 1985; 120(8): 916-7.

19. Laucks SS 2nd, Mazier WP, Milsom JW, Buffin SE, Anderson JM, Warwick MK, Surrell JA. An assessment of colostomy irrigation. Dis Colon Rectum. 1988; 31(4): 279-82.

20. Mazier WP, Dignan RD, Capehart RJ, Smith BG. Effective colostomy irrigation. Surg Gynecol Obstet. 1976; 142(6):905-9.

21. Doran J, Hardcastle JD. A controlled trial of colostomy management by natural evacuation, irrigation and foam enema. Br J Surg. 1981; 68(10): 731-3.

22. Williams NS, Johnston D. Prospective controlled trial comparing colostomy irrigation with "spontaneousaction" method. Br Med J. 1980; 281(6233): 107-9.

23. Terranova O, Sandei F, Rebuffat C, Maruotti R, Bortolozzi E. Irrigation vs. natural evacuation of left colostomy: a comparative study of 340 patients. Dis Colon Rectum. 1979; 22(1): 31-4.

24. Santos VLCG, Koizumi MS. Estudo sobre os resultados da irrigação em colostomizados submetidos a um processo de treinamento sistematizado. Rev Esc Enferm USP. 1992; 26(3): 303-14.

25. Hottenstein P. The pros and cons of colostomy irrigation. In: $11^{\text {th }}$ BIENNIAL Congress of the WCET, Jerusalem; 1996. Proceedings. Jerusalem, Israel, WCET;1996. p. 1456.

26. Turnbull GB. Managing oversight of colostomy irrigation in long term-care. Ostomy Wound Manage. 2003; 49(10):13-4.

27. Pérez-Laudo JA, Rey JG, Clavero MV. Dispositivo de 
drenaje de ostomías. ROL de Enfermería. 1994; 17(187): $79-85$.

28. Oliveira SL. Tratado de metodologia científica: projetos de pesquisas, TGI, TCC, monografias, dissertações e teses. São Paulo: Pioneira Thompson Learning; c2001.

29. Marconi MA, Lakatos EM. Metodologia do trabalho científico: procedimentos básicos, pesquisa bibliográfica, projeto e relatório, publicações e trabalhos científicos. 5a ed. São Paulo: Atlas; 2001.

30. Ventafridda V, Zanolla R. La riabilitazione dei colostomizzati. Minerva Chir. 1976; 31(8): 368-74.

31. Montandon S. L'irrigation des colostomies. Revue de l'Infermière. 1980; 7: 101-4.

32. McConnell EA. How to irrigate a colostomy. Nursing. 1990; 20(9): 78.

33. Christensen P, Olsen N, Krogh K, Laurberg S. Scintigraphic assessment of colostomy irrigation. Colorectal Dis. 2002; 4(5): 326-31.

34. Pullen RL Jr. Teaching your patient to irrigate a colostomy. Nursing. 2006; 36(4): 22.

35. Santos VLCG, Cesaretti IUR, Ribeiro AM, Filippin MJ, Lima SRS. Métodos de controle do hábito intestinal em estomizados: auto-irrigação e sistema oclusor. In: Crema E, Silva R. Estomas: uma abordagem interdisciplinar. Uberaba: Pinti; 1997. cap. 10. p. 145-62.

36. Galliani I, Santi P, Baratta B, Patrizi P. Effect of water irrigations on human colonic mucosa structure after sigmoidostomy. Dis Colon Rectum. 1987; 30(6): 453-6.

37. Terranova $\mathrm{O}$ et al. Irrigare o no irrigare il colostomizzato? Chir Triv. 1977; 17(3): 270-80.

38. Baumel H, Fabre JM, Manderscheid JC, Navarro F, Duchêne D. L' irrigation colique pour colostomies. Résultats d'une enquête nationale auprès de 795 colostomisés. Ann Chir. 1996; 50(1): 30-5.

39. Ortiz H, Martí Ragué J, Foulkes B. Indicaciones y cuidados de los estomas. Barcelona: Editorial JIMS; 1994. p. 140-2.

40. Tegido Valenti M, Nebot Salabert S, Coma Borsot A. Estudio comparativo sobre los beneficios de la irrigación de la persona colostomizada: adaptación, confort y costes. Enfermería Clín. 1999; 9(1): 7-12.

41. Gattuso JM, Kamm MA, Myers C, Saunders B, Roy A. Effect of different infusion regimens on colonic motility and efficacy of colostomy irrigation. Br J Surg. 1996; 83(10): 1459-62.

42. Viso L, Beatobe J, Galofré M. Puede un colostomizado controlar su estoma? Rev Esp Enferm Ap Digest. 1988; 74 (5): 541-2.

43. Perboni $\mathrm{C}$, et al. The cost benefit of transcultural irrigation: a multicenter study in northern Italy. WCET J. 1993; 13(4): 27-9.

44. Sadahiro S, Noto T, Tajima T, Mitomi T, Miyazaki T, Numata M. Fluctuation of blood pressure and pulse rate during colostomy irrigation. Dis Colon Rectum. 1995; 38(6): 615-8.

45. Rogenski NMB, Baptista CMC, Rogenski KE. Autoirrigação: avaliação de resultados. Rev Esc Enferm USP. 1999; 33(N Esp): 50-4.

46. Plum AV. To irrigate or not irrigate? The dilemma of sigmoid colostomy patients. WCET J. 1990; 10(2): 16-7.

47. Shaz's Ostomy Pages. Irrigating your colostomy [Internet].
Amsterdam; 2000. [citado 2006 Nov 16]. Disponível em http://www.ostomates.org/irrigation.html

48. Venturini M, Bertelli G, Forno G, Grandi G, Dini D. Colostomy irrigation in the elderly. Effective recovery regardless of age. Dis Colon Rectum. 1990; 33(12): 10313 .

49. Pietri P, Domeniconi R, Gabrielli F. Riabilitazione dell'enterostomizzato. Chir Triv. 1978; 18(3): 421-38.

50. Bail JP, Juglard G, Framery D, Deligny M, Charles JF. [Value of colonic irrigation. Long-term followed-up in 432 colostomized patients]. Presse Med. 1994; 23(36):1651-4. French.

51. Tejido Valenti M, Vargas Laguna M. Evacuación controlada en pacientes ostomizados. ROL Enfermería. 1986; 100: 109-16.

52. Seargeant PW. Colostomy management by the irrigation technique: review of 165 cases. Br Med J. 1966; 2(5504):256.

53. Santos VLCG, Paula MAB, Shido AJY, Gonçalves L; Biennial Congress of the World Council of Enterostomal Therapists (13.: 2000: Singapore). Colostomy self irrigation: an evaluating of results. In: Final Programme and Abstracts Singapore: World Council of Enterostomal Therapists, 2000. Singapore: World Council of Enterostomal Therapists; 2000. p.13; 145.

54. Kostov D, Temelkov T, Kiriazov E, Ivanov K, Ignatov V, Kobakov G. [Continent colostomy and colon irrigation]. Khirurgiia (Sofiia). 2000; 56(3-4): 39-42. Bulgarian.

55. Goode PS. Colostomy irrigation. In: Broadwell DC, Jackson BS, editors. Principles of ostomy care. St Louis: Mosby; 1982. cap. 26. p. 369-80.

56. O’Bichere A, Bossom C, Gangoli S, Green C, Phillips RK. Chemical colostomy irrigation with glyceryl trinitrate solution. Dis Colon Rectum. 2001; 44(9): 1324-7.

57. Sanada H, Kawashima K, Tsuda M, Yamaguchi A. Natural evacuation versus irrigation. Ostomy Wound Manage. 1992; 38(4): 24, 26-30, 32 passim.

58. Amdrup E, Christensen P. Colostomy care: natural evacuation or irrigation? Am J Dig Dis. 1967; 12(7): 747-8.

59. Meyhoff $\mathrm{HH}$, Andersen B, Nielsen SL. Colostomy irrigation: a clinical and scintigraphic comparison between three different irrigation volumes. Br J Surg. 1990; 77(10): 1185-6

60. O’Bichere A, Green C, Phillips RK. Randomized crossover trial of polyethylene glycol electrolyte solution and water for colostomy irrigation. Dis Colon Rectum. 2004; 47(9): 1506-9.

61. Cantone G. [La riabilitazione tardiva del paziente colostomizzato: la nostra esperienza]. Minerva Med 1985; 76(5): 143-7. Italian.

62. Sisco V, Brennan PC, Kuehner CC. Potential impact of colonic irrigation on the indigenous intestinal microflora. J Manipulative Physiol Ther. 1988; 11(1):10-6.

63. Karadag A, Mentes BB, Ayaz S. Colostomy irrigation: results of 25 cases with particular reference to quality of life. J Clin Nurs. 2005; 14(4): 479-85.

64. Riatti M, Fiore R, Granatelli MC. Long-term irrigation: the colostomist talks. In: $12^{\text {th }}$ Biennial Congress of the WCET, Brighton; 1998.Proceedings. Brighton, Inglaterra, WCET; 1998. p. 203-6. 